\title{
Visible, Unrecognisable - Recognisable, Silenced? Representations of Evangelism in Permanent Museum Exhibits in Masuria
}

\author{
Magdalena Izabella Sacha (iD) https://orcid.org/0000-0002-3233-7818 \\ Institute for Cultural Studies \\ University of Gdańsk \\ e-mail: magdalena.sacha@ug.edu.pl
}

\begin{abstract}
The article addresses representations of the Evangelical denomination at contemporary permanent museum exhibits in the region of Masuria, inhabited between 1525-1945 by a Protestant majority. Applying semiotic analysis, the author presents the outcomes of field studies in the local museums in Olsztyn, Mikołajki, Mrągowo, Ogródek, Szczytno, and in the open-air museum in Olsztynek. The principal research question is the issue of visibility and recognisability of Evangelism-related items at permanent exhibits. The author concludes that there are three types of omissions in the presentation of the history of Masurian Evangelicals. The silencing of the Protestant past of Masuria results from the cultural colonisation that took place after 1945 and from identifying Evangelicalism with Germanness in the common consciousness of the currently dominant Polish Roman Catholic community.
\end{abstract}

Keywords: permanent exhibits, museology, Evangelism, Masuria, semiotic analysis

Słowa kluczowe: wystawy stałe, muzealnictwo, ewangelicyzm, Mazury, analiza semiotyczna

\section{Preliminary recognitions}

In the 1990s, intrigued by the exclusion of the cultural artefacts of non-European people from the realm of "history" and "art," Mieke Bal proposed a comprehensive model of reading the overt and covert narratives of a museum exhibition, based on a visual analysis of exhibits and the accompanying indexes (captions, museum labels) as a communicative, semantically-indexed whole. ${ }^{1}$ Placing the art of non-European

\footnotetext{
${ }^{1}$ M. Bal, Telling, Showing, Showing off, “Critical Inquiry” 1992, vol. 18, no. 3, pp. 556-594.
} 
peoples in an exhibit staging "nature" was interpreted by Bal as an expression of colonialism, despite the apparent objectivity of the exhibition at the Museum of Natural History in New York. In this way she showed the power of semiotic analysis, coupled with an in-depth interpretation of an exhibit as a narrative constructed by the dominant strata of society, in which minorities are excluded from "history" and marginalised by being shown as part of timeless "nature." Following in the author's footsteps, I will reflect on representations of the culture of the Evangelical religious minority in museum exhibitions of a selected region of Poland.

In semiotic terms, according to Jana Scholze, an exhibit is a whole composed of objects with specific denotations which refer to their original utilitarian function. $\mathrm{Ob}-$ jects placed as exhibits in the museum context receive a secondary meaning, specific connotations. ${ }^{2}$ Thus "objects" become "semiophors" (a term coined by Krzysztof Pomian $^{3}$ ). An exhibition is a message where the authors (senders) formulate connotations offered to the public (recipients) via scenery, objects, and their descriptions. Overtly, via indices (after Charles Peirce), an exhibit imposes on the recipients specific messages, which ideally correspond to the mission of a museum institution as an archive of collective memory. Yet museums moreover communicate a specific worldview and values, which need not be explicitly stated.

Museum presentations of religion is a question at the crossroads of both religious studies and museology. Difficulties already arise at the point of classifying an object as "religious": referring to religion as an objective system, or to religiousness as a weave of subjective feelings. As Peter J. Bräunlein sarcastically claims: "An object in a museum showcase, 'religious' or non-religious, is primarily silent, although as a rule it keeps silent in a provocatively ambiguous way." ${ }^{4}$ Probably less problematic is the classification of objects of religious art and culture in systems such as Roman Catholicism or Tibetan Buddhism, which place emphasis on visual manifestations of faith, such as paintings and statues. More difficulties may arise during the classification of objects as "religious" in the case of systems questioning visual media (even to the brink of iconoclasm), such as in this discussion of Protestantism. ${ }^{5}$

Artefacts related to Protestants can be described after Anna Seemann-Majorek as Evangelism-related items: collections of texts, objects, buildings, and spaces. ${ }^{6}$ They can be found in the holdings of most Polish museums, which Seemann-Majorek has

2 J. Scholze, Kultursemiotik. Zeichenlesen in Ausstellungen, [in:] Museumsanalyse. Methoden und Konturen eines neuen Forschungsfeldes, J. Baur (ed.), Bielefeld 2010, pp. 121-148.

${ }^{3}$ K. Pomian, Zbieracze i osobliwości. Paryż-Wenecja. XVI-XVIII wiek, trans. A. Pieńkos, Warszawa 1996, pp. 44-49. The French original: Collectionneurs, amateurs et curieux. Paris, Venise, XVIe-XVIIIe siècle, Paris 1987. The notion of "semiophor" describes material objects whose cultural significance is based not on their primary material or utilitarian value, but on their derivative symbolic value, which is bestowed upon an object through placing it in the context of museum exhibitions. According to Pomian, an object that becomes a semiophor refers to the "unseen realm," that is, to symbolic values.

${ }^{4}$ P.J. Bräunlein, “Zurück zu den Sachen!" - Religionswissenschaft vor dem Objekt. Zur Einleitung, [in:] P.J. Bräunlein (ed.), Religion und Museum. Zur visuellen Repräsentation von Religion/en im öffentlichen Raum, Bielefeld 2004, p. 27.

${ }^{5}$ I use the notions of Protestantism and Evangelism interchangeably in this text.

${ }^{6}$ A. Seemann-Majorek, Ewangelikalia w zbiorach polskich - próba typologizacji / Evangelical Objects in Polish Collections - Attempt at Typology, "Muzealnictwo" 2017, no. 58, pp. 281-291. 
divided into a) thematic museums; b) local museums of varying scale and scope; and c) profiled museums, featuring the Evangelical cultural heritage. ${ }^{7}$ Poland boasts two profiled museums of Protestantism: The Museum of Protestantism in Cieszyn ${ }^{8}$ and the Museum of Polish Reformation in Mikołajki. ${ }^{9}$ Their locations indicate areas densely populated by people of Evangelical denominations, Cieszyn Silesia and Masuria; in the latter case, however, we can only refer to the area's past.

Since the sixteenth century, Masuria was inhabited by Evangelicals who spoke a dialect of the Polish language and were politically faithful to successive rulers of Prussia and Germany. In 1945, the region was incorporated into Poland as part of the so-called Recovered Territories, granted to Poland as compensation for the lands lost in the east. The population exchange led to far-reaching changes in religious relations in Masuria, where deserted Evangelical churches started to be taken over by incoming Catholics who had no churches of their own. ${ }^{10}$ In a way, Masuria became an area of Poland's colonial policy, involving the exploitation and erasure of the history of the indigenous inhabitants as "Germans." Historian Andrzej Friszke, son of an Evangelical minister, commented on the religious conflict between indigenous inhabitants of Masuria and Poles as follows:

Before 1945, the Masurian population on the territory they lived had almost no contact with the Catholics. [...] The change in the denominational structure of the country resulted in many conflicts. Most Catholics arriving from central Poland or from the Kresy (Eastern Borderlands) had had limited (if any) interaction with Protestants, knew nothing about the denomination, often fostered absurd myths, and as a rule identified Evangelism with Germanness. ${ }^{11}$

This conflict is forgotten and underestimated in the collective consciousness; Poles see Masuria solely as a land of exquisite nature. However, the history and culture of Masuria, uniformly Protestant from 1525 to 1945, is presented in regional museum institutions. What artefacts and index signs are used to represent the Protestant denominations of historical Masuria during present-day permanent exhibitions? This is my principal question of interest here.

\section{Visible and recognisable? Exhibits of Evangelism-related items in selected museums}

The 500th anniversary of the Reformation in 2017 was an opportunity to hold temporary exhibitions on Protestantism in many Polish museums. For a short time, Evangelical culture and art became visible in exhibition space. However, I am specifically

${ }^{7}$ Ibidem, p. 282.

${ }^{8} \mathrm{https}: / /$ muzeumprotestantyzmu.luteranie.pl/ [access: 16.07.2020].

${ }^{9} \mathrm{http} / / /$ www.mikolajki.luteranie.pl/muzeum-reformacji/ [access:16.07.2020].

${ }^{10} \mathrm{~K}$. Bielawny, Kościół ewangelicko-augsburski na Warmii i Mazurach po II wojnie światowej w spojrzeniu historyczno-ekumenicznym, ch. 3: Problemy z obiektami sakralnymi w Kościele Ewangelicko-Augsburskim, Olsztyn 2008, pp. 136-222.

${ }^{11}$ A. Friszke, Ksiadz Edmund Friszke - dramat polskiego ewangelika, [in:] Ewangeliccy duchowni i parafianie. Powojenne lata w Olsztynie i na Mazurach, S. Kruk (ed.), Olsztyn 2007, p. 41. 
interested in permanent exhibits as lasting visual self-presentations of cultural heritage and social memory of the regional community. They are highlights of museum facilities and constitute proof of a museum's mission. More fully than exclusive temporary exhibitions, permanent exhibits reflect the attitude of the dominant majority towards the minorities. On the other hand, it is precisely the innovative temporary exhibitions that often become the harbinger of positive change in the existing ideas perpetuated and ossified in permanent exhibits.

I will be analysing ways of representation, namely visibility and recognis ability of Evangelism-related items, at permanent exhibits of museums in Masuria. For me, the term visibility denotes a placement of an artefact in an exhibit by a decision of the exhibit's curators. The notion of re $\operatorname{cog}$ nisability, in turn, is used by me not only in terms of the object's display and making it visible, but first of all as the endowment of this object with connotations via indices: the textual content of captions, museum labels, and the like. In the specific denominational context I examine, a recognisable exhibit is an object endowed with a connotation referring to Evangelism. Thus unrecognizability is a situation where a visible artefact that meets the criteria of an Evangelism-related item is defined at the exhibit via labels that leave out the context of Protestantism, offering it a connotation referring the visitor to other ideas. My analysis of permanent exhibits will demonstrate how Evangelismrelated items are displayed and what types of omissions in the content of index signs result in the unrecognizability of exhibits as objects related to the Evangelical tradition. In my opinion, marginalization of the religious (Evangelical) connotation of objects demonstrates a colonial approach of the Roman Catholic majority of Polish society after the annexation of Masuria to Poland following World War II.

The Museum of Polish Reformation in Mikołajki is profiled in terms of Protestant themes. This ecclesiastical museum was established in 1973 under the auspices of the minister of the Evangelical parish, the Rev. Władysław Pilch. It is currently run by the Parish Community of the Holy Trinity Evangelical Church of the Augsburg Confession in Mikołajki, which made a former school building near the church available for the museum's premises.

In terms of layout, the museum is a unique collection of texts. The exhibit consists of 40 glass showcases filled with prints and books related to the Reformation (including about 300 copies of precious historical texts). The showcases provide extensive explanations which make up a bibliography of the books on display. The labels on the walls offer information on the course, chronology, and major figures of the Reformation. The exhibition moreover features a small number of artefacts related to Evangelism, such as gowns, harmoniums and even skis used by Adam Małysz, a famous Polish ski jumper and Lutheran.

This type of exhibit arrangement can be called a library. However, this is not a typical library, as the books and prints are presented as items under glass panes and not as texts to be read. This is the role of large museum labels, functioning as index signs. It takes the visitor about three hours to become familiar with the information boards and labels. The exhibits as Evangelism-related items are recognisable in a redundant way, by providing detailed and superfluous information on individual objects, figures, and the historical context of the Reformation. 
This hyper-recognisability can be accounted for by the fact that the majority of Evangelism-related items are precisely books and prints, due to, among other factors, the aforementioned iconoclastic tradition of Protestantism and the focus on the Word (sola scriptura). However, in Masuria, incorporated in 1945 into Poland, with a marked Roman Catholic majority, the very possession of Evangelical texts, especially in German, might have brought about persecution on the part of both the communist regime and the settlers incoming from the regions of the old Eastern Borderlands (pl. Kresy) and central Poland. Books were often destroyed as "German," even if they were published in Polish. The mission of the museum's founder, the Rev. Pilch, was to save many precious religious books from destruction. This is borne out by the caption under the clergyman's portrait placed near the entrance to the exhibit: "The pastor's love for collecting Old Polish Reformation printed word (printed in Gothic) became a pretext for his arrest and imprisonment, which lasted several months." ${ }^{2}$ In this context, the redundancy of indices and the presentation of a collection of books by the Evangelical organisers of the museum is no longer surprising, as theirs is a rescue mission.

The Michał Kajka Museum in the village of Ogródek, Orzysz Commune is a thematic biographical museum. The museum's history harks back to 1968, when an exhibit dedicated to the biography of Masurian carpenter and social activist Michat Kajka (1858-1940) was launched in the house built by this folk poet in $1886 .{ }^{13} \mathrm{At}$ present, the museum is run by the local government of the County of Pisz. A new permanent exhibit was launched in the museum in $2014 .{ }^{14}$ The innovative arrangement manifests itself both in the selection of the content in the biographical section of the exhibit and in the choice of elements of the exhibition, genuine objects connected with Masurian households and literature, and the scenography: large-sized bulletin boards and prints as well as multimedia, which play an important role in familiarizing the visitor with the content of written and photographic resources. The exhibition is divided into thematic sections: "History," "Writing in Masuria," and "Michał Kajka." In the section devoted to Masurian writing, the visitor will find exhibits related to Evangelism - Kajka's religious denomination.

Evangelism-related items make up a veritable "island," ensconced in two glass display cases against the backdrop of a photograph of an Evangelical church in the nearby village of Klusy. Placed in the showcases are religious books with title pages visible, such as Nowo wydany Kancyonat Pruski (New Edition of a Prussian Hymnal; Königsberg 1907 and 1913). In addition, a visitor may leaf through the digitalized Prussian Hymnal in its 1741 Königsberg edition on a display panel. The visitor thus has contact with the exhibit, being the genuine object, and can read its content, meaning one can access the object's original function. A lack of digitalization makes the latter impossible in the Museum of the Reformation in Mikołajki.

The exhibit in the Michał Kajka Museum has an attractive, modern layout. The Protestant elements and references are presented as part and parcel of the literary

\footnotetext{
${ }^{12}$ Copied from the description below Rev. W. Pilch's (Pilchowski's) photograph.

${ }^{13} \mathrm{http}: / /$ www.michalkajka.pl/ [access: 16.07.2020].

${ }^{14}$ Information from the bulletin board on the exhibit in the Museum in Ogródek.
} 
biography of the folk poet via exhibits such as books (as original objects and in digital form), magazines and poetry. The exhibit is communicative thanks to the multiplicity of the index signs used - captions, labels, and movies to be accessed on multimedia displays. The narrative about Evangelism is a logically inherent part of the biographical narrative about Michał Kajka as a person, and the Evangelism-related items are recognisable in a manner appropriate to the subject matter.

Museums such as the biographical museum in the village of Ogródek are indeed rare. Far more characteristic of the landscape of former East Prussia are regional museums located in towns, established as so-called Heimatmuseen in the early twentieth century, at the time of burgeoning regionalism and construction of a German national identity. The Museum of Masuria in Szczytno, now one of the branches of the Museum of Warmia and Masuria in Olsztyn, continues the tradition of the preWorld War II German Kreisheimatmuseum (Museum of Local History). ${ }^{15}$ At that time, the museum was established in the city centre, in the former castle of the Teutonic Knights. Its collection focused on ethnography, sacred art, numismatics, and archaeological, natural, and geological objects. Despite the wartime destruction, the holdings of the Szczytno Museum have fortunately survived and around 600 objects have been preserved. ${ }^{16}$ Moreover, there is an active Evangelical parish in Szczytno.

The layout of the permanent exhibit concerning the history of Szczytno/Ortelsburg includes display cases with exhibits, accompanied by large-sized information boards and graphics showing the town destroyed during World War I. The display cases contain books, newspapers and magazines, objects of daily use, and craftsmen's items. The index signs denoting the exhibits refer to the general theme of a given showcase, for example "Hymnals Religious Literature" [sic!], "Polish Press in Masuria," "Publishing Centres in Masuria (19th c.)," "Publishing Houses in Königsberg," "Polish Movement in Masuria," and others. Only a few objects come with labels indicating the context of their origin.

Religious references can be found in the showcase marked as "Hymnals Religious Literature." We can find here original religious books, such as Kazania na Lekcye roku kościelnego ks. Wilhelma Ziethe (Sermons for the Readings of the Ecclesial Year by the Rev. Wilhelm Ziethe; Königsberg 1892); Psalmy Dawidowe, Ustawy Kościelne Królestwa Pruskiego (The Psalms of David, Ecclesial Acts of the Kingdom of Prussia; Königsberg 1731). However, the fact that these are Evangelical publications is left to the visitor's guesswork, as the labels offer no such information. The case labelled "Polish Press in Masuria" displays the originals and copies of Masurian newspapers and magazines. The labels offer information about the editors, dates, and places of publication of individual titles.

In terms of the presentation of Evangelism-related items under examination here, the permanent exhibit in the Museum of Masuria in Szczytno seems visually incommunicative despite the recognisability of multiple historical texts, which might otherwise serve as a starting point for an Evangelism-related narrative. For example, the section titled "Religious Literature" lacks descriptions to familiarise the

\footnotetext{
${ }^{15} \mathrm{http}: / /$ muzeumszczytno.art.pl/2-O-muzeum.html [access: 4.06.2017].

16 Ibidem.
} 
visitor with the differences between the Christian denominations in Masuria, while in the "Publishing Centres in Masuria" section the principal connotation imposed by the Museum is the link to Polish publishers, leaving out the religious content of the books. Evangelism-related items are visible yet unrecognisable. They are auxiliary to the principal museum narrative showing Masuria as a place of conflict between nineteenth- and twentieth-century Polish and German nationalisms. The 2017 anniversary of the Reformation provided no fresh impetus for the permanent exhibit and in 2020 the theme of a clash of nationalisms was additionally enhanced by a temporary exhibition dedicated to the centennial of the 1920 plebiscite, which Poland lost in Masuria.

Another branch of the Museum of Warmia and Masuria in Olsztyn, similar in its urban character to the Museum of Masuria in Szczytno, is the Mraqgowo Museum. ${ }^{17}$ Set up in the 1960s on the basis of holdings of a regional chamber, in the 1970s it was incorporated into the Museum in Olsztyn as its branch. The permanent exhibit in the Mragowo Museum showcases the prehistory of the region and the history of Mrągowo, known pre-World War II as Ządźbork (Sensburg). While the section related to prehistory is a powerful element of the permanent exhibit, mainly thanks to the attractive artefacts from archaeological digs and communicative labels, the exhibition room dedicated to the modern history of the town, with significant Evangelismrelated items, seems a museum relic of the 1970s in terms of layout.

The "The History of Mrągowo" room is dominated by a portrait of the post-war namesake of the town, Christoph Coelestin Mrongovius [Mrongowiusz] (17641855), an Evangelical clergymen, ethnographer and lexicographer, who at a time of intensified Germanisation of school education in the Kingdom of Prussia made a name for himself as a defender of education in the Polish language in elementary schools. It is precisely this very role of the eminent scholar that was taken advantage of in the post-war Polonisation of Masuria by the Polish authorities, who decided to give the town of Ządźbork/Sensburg the artificially created name "Mrągowo." Mrongowiusz himself had nothing to do with Sensburg in his long life.

I am afraid that the artificiality of Mrongowiusz's patronage over the town reflects the arrangement of the permanent exhibit. The portrait of the preacher is accompanied by an extensive biography, while the showcase features objects related to the clergyman: the books and sermons he published, a copy of a letter of his, a faded photograph of his family house in Olsztynek, and commemorative medals with Mrongowiusz's portrait. Successive display cases include such Evangelism-related objects as copies of an eighteenth-century illustrated Dilherr Bible, ecclesiastical books, chalices, and platters. Interestingly, to mark the 500th anniversary of the Reformation, the Mraqgowo Museum for a few months held a temporary exhibition dedicated to the Evangelical community in former Sensburg, ${ }^{18}$ which in no way impacted the recognisability of the Evangelism-related objects in the permanent exhibit.

\footnotetext{
${ }^{17} \mathrm{https}: / /$ mragowo.muzeum.olsztyn.pl/ [access: 16.07.2020].

${ }_{18} \mathrm{http}: / /$ mragowo24.info/news/5364-500-lat-reformacji-w-mragowie-nowa-wystawa-w-muzeum [access: 15.07.2020].
} 
Curious at the permanent exhibit is first and foremost the short biography of Mrongowiusz, the most significant index sign here. The scholar is called "the patron of the town," "a man of encyclopaedic knowledge," and one of "the most outstanding representatives of Polish regional literature in the Prussian partition." Information also includes the fact of his birth in Olsztynek and learning in the "cathedral school in Königsberg, where in 1782 he started theology studies." Further on the text refers to the 57 years he spent in Gdańsk/Danzig, where he "taught the Polish language in the Academic Gymnasium." Nowhere, however, can the visitor find information about Mrongowiusz's religion, his role as an Evangelical preacher, or his birth as a son of a minister. These facts are missing from the mentions of his studies in Königsberg or work in the Academic Gymnasium in Gdańsk, one of the most important Protestant high schools in Royal Prussia. Paradoxically, the only place where the term "Evangelical" appears is at the bottom of the portrait, with the caption in German: "Christoph Coelestin Mrongovius Evangelisch: poln: Prediger zu St: Anna: geb: in Hohenstein in Ost Preußen 1764 d: 19 Juli: gest: in Danzig 1855 d: 3 Juni:." We may bitterly observe that the Prussians in the nineteenth century never concealed the fact that Mrongowiusz was a Polish preacher ("poln: Prediger"), yet at present the information about the Evangelical denomination of the town's patron is marginalised and left out.

These museums in Szczytno and Mrągowo are branches of the biggest museum institution in the Warmińsko-Mazurskie Region: the Museum of Warmia and Masuria in Olsztyn. The institution is atypical in light of the adopted selection criteria in that its principal premises are located in Warmia rather than in Masuria. A sufficient justification for including it in the research is, first, the central position of the institution in the region (since 2006 it has been listed in the prestigious State Register of Museums); second, its location in a central place, connected since the Middle Ages with religious and secular power, the former castle of the Warmian Chapter, ${ }^{19}$ which after the takeover of the Diocese of Warmia by the Kingdom of Prussia in the wake of the first partition of Poland in 1772 became a centre of a Lutheran community; third, the presentation, as of December 2013, of the temporary exhibition Lutheran Epitaphs and Supplementary Portraits. ${ }^{20}$ Since the exhibition has been on for the past seven years, it can be regarded as permanent.

The exhibition is located in the prestigious Gothic wing, in the rooms adjacent to the former quarters of the castle administrators, including the most famous one, Nicolaus Copernicus (the administrator of the Olsztyn Castle between 1516 and 1521). These are the rooms of the former refectory and chapel, connected among others with the history of the Evangelicals in Catholic Warmia. The Lutheran community in Olsztyn was established in 1779, after most of the property was taken away from the Roman Catholic Church in Warmia under the patent of King Frederick II

19 A. Rzempołuch, Przewodnik po zabytkach sztuki dawnych Prus Wschodnich, Olsztyn 1993, pp. 103-105.

${ }^{20} \mathrm{http}: / /$ muzeum.olsztyn.pl/2268,Luteranskie-epitafia-i-portrety-upamietniajace.html [access: 6.06. $2017]$. 
of Prussia in $1772,{ }^{21}$ which made it possible for the Evangelicals to establish their headquarters in the former castle of the Bishops of Warmia. Lutherans remained in the castle until 1877, when an Evangelical church was built in Olsztyn/Allenstein.

Two rooms occupied by Evangelicals in the nineteenth century have since 2013 featured an exhibit of Lutheran epitaphs. Collected here are epitaphs and portraits of Prussians of all social strata from the rule of the House of Hohenzollern: rulers, nobles, clergy, townspeople, and peasants. The exhibition includes a total of $33 \mathrm{se}$ pulchral and commemorative works, including ten integral epitaphs, as well as numerous portraits painted during the sitters' lifetime by both outstanding artists and dilettantes. A seventeenth-century portrait of a peasant, the mayor of the village of Tołkiny n. Kętrzyn, stands out from other works of the period in terms of the naturalness of the image. The funeral flag of Johann von Kreytzen hangs down from the vault of the former chapel. Unusual artefacts of outstanding artistic value include a monumental sixteenth-century epitaph of a bourgeois family from Bartoszyce and a dowry box of Catherine von Dönhoff (née Dohna) with the owner's portrait.

Apart from the part of the exhibition arranged as a portrait gallery, there is also a section recreating a sacred interior in the former castle chapel..$^{22}$ Books and utensils tied with the Evangelical liturgy are used here. Among the displays are a book cover from the Silvern Library, originally held in the Albrecht Hohenzollern Library in the Königsberg Castle (1556) and a Dilherr Bible (published in Nuremberg in 1706). Gold items on display include a baptismal font, altar candlesticks, a silver chalice cup, and a pyx for hosts. The objects come from places that are no longer physically accessible, either no longer in existence, taken over by Catholics, or separated by the state border, which in 1945 divided the culturally dense area of East Prussia between Poland, Lithuania and Russia.

Descriptions of the exhibits, including mainly epitaphs, are sparing and factual: they include the name of the deceased, dates of birth and death, possible attribution of authorship, and information about the object's provenance and technique of execution. Constructed in this way, the index signs do not impose any interpretation on the visitor. They connote Evangelism as historical and aesthetic objects of art and crafts related to sacred spaces, referring to the specific deceased. Unfortunately, the exhibition space lacks an introduction with information about the unique nature of Protestant art, or about the Evangelical community in Warmia and Masuria. The exhibition is more of a space for reflection and "face to face" encounters with the deceased than a place to acquire knowledge. Proper understanding of the cultural and religious context of the objects requires that the viewers have a high degree of expertise. Left without any description of the cultural and historical context, Evangelism-related objects become objects of aesthetic contemplation.

Open-air museums are a specific type of thematic museum usually located in rural areas. In Masuria this type of museum is represented by the Museum of Folk

${ }^{21}$ Zamek Olsztyn. Przewodnik ilustrowany, teksty do przewod. A. Rzempołuch, Warszawa 2013, pp. $12-13$.

${ }^{22}$ http://muzeum.olsztyn.pl/2268,Luteranskie-epitafia-i-portrety-upamietniajace.html [access: 6.06. $2017]$. 
Architecture -Ethnographic Park in Olsztynek. ${ }^{23}$ I will discuss this case due to a change in the index signs occurring between 2017 and 2020 in the face of external criticism.

The Ethnographic Park and the town centre are four exhibition spaces that can be classified as Evangelism-related items. These are: 1) Reconstruction of an Evangelical rectory in a copy of a cottage from Bartężek in Olsztynek; 2) Replica of an Evangelical church from Rychnowo; 3) Exhibition Salon in Olsztynek in the former Evangelical church; 4) Mrongowiusz's house in Olsztynek, the eminent scholar's birthplace. The first two are open-air spaces. The exhibition principle here is consistent staging (in Jana Scholze's classification ${ }^{24}$ ), or the practice of "imitating reality." This means that individual objects do not bear index marks because they are supposed to create in the eyes of the recipient the illusion of a "genuine interior" supposed to "speak for itself." This is how the space is organised in the reconstruction of the Evangelical rectory and in the replica of the church from Rychnowo. Both buildings are twentieth-century copies..$^{25}$ In 2017, the main labels at the building entrances provided only basic information such as building type, dating and region, leaving out information on the layout of the interiors or denominational provenance.

The layout of the premises of the so-called Evangelical presbytery in the house from Bartężek is basically clear to the visitor, despite the lack of labels on individual exhibits. Especially noteworthy among objects of religious character are a sturdy crucifix and a lithograph depicting a scene in a church. In the open wardrobe the visitor can see a gown on a hanger. A watchful visitor will catch sight of a portrait of Martin Luther after the famous Cranach painting. There are hefty official and religious books on the table. The rectory is moreover the imaginary space of the minister's family's everyday life.

The Evangelical rectory was arranged in 2013 and was specially furnished for this purpose by Evangelicals (Lutherans and Methodists) from Olsztynek and Germany. ${ }^{26}$ To mark the launch of the exhibit, the director of the open-air museum observed: "The most intriguing objects at the show include a nineteenth-century harmonium we have received from the Association of Friends of Masuria from Scharnebeck, Germany, a gown with preaching tabs, a liturgical shawl donated by the Rev. Friedrich Tegler, as well as old ecclesial prints and theological literature." ${ }^{\prime 27}$ That is why my doubts were raised by the later rearrangement of the exhibition in relation to its original version, on display in the year of the Reformation Anniversary. In 2017, the

${ }^{23} \mathrm{http}: / /$ www.muzeumolsztynek.com.pl/ [access: 16.07.2020].

${ }^{24}$ Scholze distinguishes several types of museum exhibitions: a) classifications (Klassifikation), b) chronologies (Chronologie), c) staging (Inszenierung), d) compositions (Komposition); for more on this matter, see: J. Scholze, Medium Ausstellung. Lektüren musealer Gestaltung in Oxford, Leipzig, Amsterdam und Berlin, Bielefeld 2004.

${ }^{25}$ W. Chodkowska, M. Sabljak-Olędzka, Z. Adamiec, Historia Ostpreußisches Heimatmuseum w Królewcu, Olsztynek 2015, pp. 22-23.

${ }^{26}$ M. Żebrowska, Rekonstrukcja wyposażenia plebanii ewangelickiej z Mazur z poczatku XX wieku w Muzeum Budownictwa Ludowego - Parku Etnograficznym w Olsztynku, "Zeszyty Naukowe Muzeum Budownictwa Ludowego - Park Etnograficzny w Olsztynku” 2013, no. 4, pp. 149-155.

${ }^{27}$ E. Wrochna, Działalność Muzeum Budownictwa Ludowego - Parku Etnograficznego w Olsztynku w roku 2013, "Zeszyty Naukowe Muzeum Budownictwa Ludowego - Park Etnograficzny w Olsztynku" 2014, no. 5, p. 114. 
aforementioned harmonium was moved to a temporary exhibition of folk musical instruments, where it was an exhibit with a primary connotation related to music, with its secondary connotation referring to Protestantism obliterated. This was not in line with the intention of the donors, for whom the religious connotation was primary, and the purpose of handing over the instrument to the museum was to emphasize the role of music in the lives of Evangelicals.

Another interesting exhibit on the premises of the open-air museum is a wooden church from Rychnowo (also a twentieth-century copy). It recreated the wall painting and partly also the furnishings, such as pews, balcony, pulpit, and patrons' stalls. The original altar was transferred from the church in Różyńsk Wielki. On the back wall behind the altar, hidden from the eyes of the faithful sitting in the pews, there is a painting depicting a larger-than-life figure of Martin Luther. In this building, the index signs do not indicate the religious provenance of the building. In 2017, an inscription on a board on the outer wall of the church provided enigmatic information in three languages (Polish, English, German) that it was a "church courtyard" featuring, for example, exhibit "10a. Church from the village of Rychnowo (Grunwald Commune, Ostróda County, copy of a 1714 building)." ${ }^{.28}$

The objects in the interior of the church - in accordance with the traditional openair museum principle of "staging reality" - do not bear labels that would explain to the individual visitor the meaning of the paintings and furnishings. Elements that could indicate Protestant provenance (e.g. Luther's portrait) are hardly visible in their locations. My observation of the visitors' behaviour showed that some of them automatically interpreted the church building at the open-air museum as a sacred Catholic zone, as evidenced by the gestures of crossing oneself at the threshold of the church and kneeling before the altar. Thus, visitors adjust the object they are visiting to their own Roman Catholic cultural context, and the museum institution does not offer them any other connotation referring to the Evangelical context, because the index signs are either too vague or absent.

In 2018, I was invited by the Masurian Evangelical Society to give a lecture on the subject of index signs in the museums in Masuria, ${ }^{29}$ including primarily those in the Olsztynek open-air museum, popular among tourists. Possibly, this meeting, attended by a Museum employee, led to a correction of the labels and today the church from Rychnowo is referred to as an Evangelical church (a change in visitors' behaviour is noticeable: they maintain peace and quiet without making gestures characteristic of Catholic sacred spaces), and the Evangelical rectory was supplemented with a comprehensive description of religious diversity in the Masuria region, illustrated by a picture of the "lost" harmonium returned to its destination. Labels describing the features of interiors have appeared in other buildings as well.

28 The inscription rewritten from the museum label.

29 A lecture based on the presentation of results of 2017 field studies as addressed in the article: M.I. Sacha, Bible, Gown, Harmonium... The Memory of Protestantism at Museums in Masuria, "Przegląd Zachodni” 2018, pp. 241-266. 


\section{Masurian Evangelists - visible, recognisable, silenced?}

According to Pauline Turner Strong, semiotic analysis indicates the power patterns reflected in the selection of exhibits and the content of museum labels:

The semiotic model offers a particularly systematic and integrated approach to the relationship between representation and communication in museums - an approach that reveals some of the more subtle ways in which labels function not only as sources of information and interpretation but also as mechanisms of social inclusion or exclusion. ${ }^{30}$

This study has focused on visual index signs. They are primarily aimed at the individual visitor (visitors organised in groups are usually offered guided tours by a museum employee, whose narration may vary depending on the expectations and conditions of the group). The curator of the exhibition, through the selection of the object, its contextualisation in relation to other exhibits, descriptions, and labels, imposes on the visitors a certain set of overt connotations. The captions and labels do not operate in a void but refer to the pre-existing knowledge of the exhibition audience, knowledge that the visitor has and wants to deepen through a visit to the museum. This pre-knowledge, resulting from cultural capital, is a starting point for the connotations that arise in the mind of the visitor. In the case of individual visitors, their stock of classified connotations is basically impossible to determine: it depends on their cultural and intellectual competence, personal experiences, and emotions. What can be objectively investigated are the connotations overtly imposed by the museum.

A study of index marks reveals a certain pattern of omissions which make a given item visible yet unrecognisable at the exhibit as an "Evangelical" object. I propose naming three kinds of omissions identified in permanent exhibits in Masuria:

a) Use of a general (superior) category,

b) Use of another equivalent category,

c) Aestheticization.

The most frequent omission (type $a$ ) of the non-Catholic classification of an object is the use in its description of a semantically superior category, a general reference to religion, including "church," "chalice," "parish ledger," "songbook," "religious literature," and "theological studies." The index sign points to a general category. Omissions of this kind result in the recipients' assignment of their own unique religious assumptions to general categories. In Poland, these images are mostly related to Roman Catholicism. Through this type of general connotation, the image of the world in the mind of the recipient remains intact: the recipient "sees" what he knows. His or her knowledge is not enhanced after a visit to the museum, but rather enriched with aesthetic impressions connected with admiring allegedly "familiar" artefacts.

Omissions of type $b$, consisting in the use of an equivalent category with respect to the denominational classification, are less frequent. For example, the harmonium donated to the museum to demonstrate the role of music in the lives of Evangelicals

${ }^{30}$ P.T. Strong, Exclusive Labels: Indexing the National "We" in Commemorative and Oppositional Exhibitions, "Museum Anthropology" 1997, vol. 21, no. 1, p. 42. 
became an exhibit at a show of folk musical instruments (even though it is not a folk instrument), or Evangelical press presented solely as "Polish publications," as it is printed in that language. Omissions of this type are linked to the overarching narrative of the exhibit and the museum's mission.

Aestheticization (type $c$ ) is the most subtle and least invasive type of omission. We encounter it at exhibitions where the decisive voice belongs to art historians-curators. The selection of the exhibits follows the criteria of aesthetic beauty and artistic value, while the descriptions of the exhibits focus on the provenance of the objects (technique of execution, craftsmanship, original place of display) and their owners, who were mostly of the higher social strata. The context of Evangelical everyday life is missing from such exhibitions, while the knowledge of the visitor is expanded with detailed information about historical works of art. The reception of the exhibition is mainly aesthetic.

The outlined three types of omission of the Evangelical provenance of the objects arise on socio-cultural grounds. Making a reference to Jana Scholze's model of semiotic analysis mentioned at the beginning, one reason may be the meta-communicative aspect of a museum exhibit. As Scholze observes:

Exhibition metacommunication refers to all communication phenomena that do not relate directly to the history of the objects or the topic of the exhibition, but rather to the academic, museological, political, and individual views that underpin the exhibit. Thus, metacommunication turns to sign systems outside the context of the exhibition, but not in the sense of pointing to objects as such, but pointing to objects as sign systems, i.e. cultural phenomena [operating] within the order of meaning. ${ }^{31}$

From this perspective, in Poland the socio-political context is delineated by the predominant role of ideas and stereotypes related to the Roman Catholic faith. Just as the American colonialism decoded by Mieke Bal, seemingly invisible, manifests itself by assigning artefacts of indigenous peoples to the order of Nature rather than Culture, in Poland religious colonialism within Christianity manifests itself in a seemingly insignificant way by assigning specific objects to either superior or equivalent categories, nevertheless consistently overlooking their non-Catholic provenance.

In museums in Masuria - for four hundred years the place of residence of Protestants of various denominations, united in the Prussian Union of Churches - the run-of-the-mill visitor will learn little about this aspect of regional history from the current permanent exhibitions, while temporary exhibitions, such as the excellent "Annunciation for the Eyes" at the Nicolaus Copernicus Museum in Frombork (July 2018-July 2019), come and go virtually unnoticed. Some of the permanent exhibitions have their roots in the period of the People's Republic of Poland, when not

31 "Die Metakommunikation von Ausstellungen betrifft alle Kommunikationsphänomene, die sich weder direkt auf die Objektgeschichte beziehen noch auf die Ausstellungsthematik, sondern auf der Präsentation zugrundeliegende akademische, museologische, politische und individuelle Standpunkte. Damit wendet sich die Metakommunikation immer Zeichensystemen außerhalb des Ausstellungskontexes zu, doch nicht im Sinne des Verweisens auf die Gegenstände an sich, sondern auf diese als Zeichensystem, d.h. als kulturelle Phänomene innerhalb der Zuordnungen von Bedeutungen.” J. Scholze, Medium Ausstellung..., op. cit., p. 36. 
only specifically Evangelical but more generally religious themes were marginalised. Exhibitions created after the period of political transformation include Evangelical themes in a context appropriate to the mission of a given museum, such as biographical or ethnographic. The museums of northern Poland are yet to develop a narrative about Evangelicals as a legitimate part of the region's history.

Translated by Marcin Turski

\section{Bibliography}

Bal M., Telling, Showing, Showing off, "Critical Inquiry" 1992, vol. 18, no. 3, pp. 556-594.

Bielawny K., Kościół ewangelicko-augsburski na Warmii i Mazurach po II wojnie światowej w spojrzeniu historyczno-ekumenicznym, vol. 3: Problemy z obiektami sakralnymi w Kościele Ewangelicko-Augsburskim, Olsztyn 2008.

Bräunlein P.J. (ed.), Religion und Museum. Zur visuellen Repräsentation von Religion/en im öffentlichen Raum, Bielefeld 2004.

Chodkowska W., Sabljak-Olędzka M., Adamiec Z., Historia Ostpreußisches Heimatmuseum w Królewcu, Olsztynek 2015.

Kruk S. (ed.), Ewangeliccy duchowni i parafianie. Powojenne lata w Olsztynie i na Mazurach, Olsztyn 2007.

Pomian K., Zbieracze i osobliwości. Paryż-Wenecja. XVI-XVIII wiek, trans. by A. Pieńkos, Warszawa 1996.

Rzempołuch A., Przewodnik po zabytkach sztuki dawnych Prus Wschodnich, Olsztyn 1993.

Sacha M.I., Bible, Gown, Harmonium... The Memory of Protestantism at Museums in Masuria, "Przegląd Zachodni" 2018, pp. 241-266.

Scholze J., Kultursemiotik. Zeichenlesen in Ausstellungen, [in:] Museumsanalyse. Methoden und Konturen eines neuen Forschungsfeldes, J. Baur (ed.), Bielefeld 2010, pp. 121-148.

Scholze J., Medium Ausstellung. Lektüren musealer Gestaltung in Oxford, Leipzig, Amsterdam und Berlin, Bielefeld 2004.

Seemann-Majorek A., Ewangelikalia w zbiorach polskich - próba typologizacji / Evangelical Objects in Polish Collections - Attempt at Typology, "Muzealnictwo" 2017, no. 58, pp. 281-291.

Strong P.T., Exclusive Labels: Indexing the National "We" in Commemorative and Oppositional Exhibitions, "Museum Anthropology" 1997, vol. 21, no. 1, pp. 42-56.

Wrochna E., Działalność Muzeum Budownictwa Ludowego - Parku Etnograficznego w Olsztynku w roku 2013, "Zeszyty Naukowe Muzeum Budownictwa Ludowego - Park Etnograficzny w Olsztynku” 2014, no. 5, p. 114.

Zamek Olsztyn. Przewodnik ilustrowany, teksty do przewod. A. Rzempołuch, Warszawa 2013.

Żebrowska M., Rekonstrukcja wyposażenia plebanii ewangelickiej z Mazur z poczatku XX wieku w Muzeum Budownictwa Ludowego - Parku Etnograficznym w Olsztynku, "Zeszyty Naukowe Muzeum Budownictwa Ludowego - Park Etnograficzny w Olsztynku” 2013, no. 4, pp. 149-155. 